\title{
IMPLICATIONS OF HIGHWAY DEVELOPMENT AND EXPANSION ON URBAN RESIDENT IN NIGERIA: A CASE STUDY OF ABEOKUTA METROPOLIS
}

\author{
O. J. Afolabi ${ }^{1, *}, 0$. A. Oyetubo ${ }^{2}$ and O. A. Oluwaji ${ }^{3}$ \\ 1,3, Department of Management Technology, Bells University of TeChNOLOGy, OTA, OGUn STATe, NigERIA

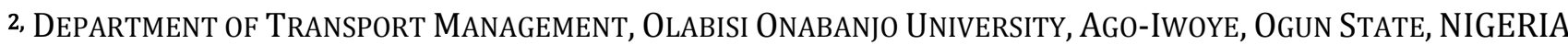 \\ E-mail addresses.1afolabiseyo@yahoo.com, 2 oyetuboadebayo@gmail.com,3 lekanioluwayi@gmail.com
}

\begin{abstract}
Roads remain the major tool for facilitating the mode of moving goods and people across the country to accelerate economic and business activities. Modern businesses, industries, trades and general activities depend on transport and transport infrastructure, the movement of goods and services from place to place becoming vital and inseparable aspects of global and urban economic survival. This study examined the implications of highway development and expansion on urban residents in Abeokuta city. Data was obtained from the administration of questionnaires to 545 residents of Abeokuta city, who were randomly selected. Simple descriptive statistics and Analysis of Variance (ANOVA) were employed. The findings show that the traffic flow was found to be very smooth and free due to the wide and good condition of the highway; the residents stated that highway expansion allow increase in inflow of new residents, businesses and puts pressure on the existing houses thus there is increase in value of houses as a result of increase in demand; residents believe that the expansion of roads has opened up the area for more businesses which now causes high cost effect on rent and leases in the study area. The research suggests that all road designs, construction and rehabilitation work should be handled by competent engineers who must give guarantee on the roads for a specified period. The proper functioning of an urban area depends on an efficient transportation network; this contributes to the economy of Abeokuta directly through influx of people.
\end{abstract}

Keywords: Sustainable, Transport System, Highway Development, Road Expansion.

\section{INTRODUCTION}

Transportation infrastructural development is undertaken to improve accessibility at a regional or urban level and to relieve traffic congestion in these areas. This development is evaluated by property owners and residents in the affected areas; however, the effect of new roads or highways in particular, may have both positive and negative effects on the housing. Improved accessibility may shift housing prices upwards, whereas higher traffic noise levels and increase in traffic density may reduce prices in houses that are adjacent to the new road [4].

Physical accessibility is determined by the time and cost of travel to other locations. It depends on the presence, efficiency and effectiveness of transport modes. Investment in new transport infrastructure will alter location's relative accessibility, inducing both localised and more general changes in land values. Substantial value changes will trigger property investment and development decisions, resulting in the intensification or change in land use. Therefore, property market acts as the conduit through which the economic and social impact of changes in accessibility is transmitted to the environment. Aderamo [2] opines that road network constitutes an important element in urban development as roads provide accessibility to the different land uses in the urban area. Thus, the proper functioning of an urban area depends on an efficient transportation network and general accessibility largely depends on transport facilities.

Masogunje [7] documented that the history of road transport in Nigeria dates back to 1904 when Lord Luggard attempted the construction of a mule road linking Zaria and Zungeru in the Northern States of Nigeria. The road was later extended from Zaria to Sokoto, Katsina and Maiduguri. However, the road linking Ibadan and Oyo constructed in 1906 is recorded to be the first motorable road ever constructed in Nigeria. At independence in 1960, the Nigerian landscape was dotted with a skeletal network of trunk roads as well as secondary and feeders roads that exhibited the characteristics which reflected the 
purpose of their construction. They were narrow and winding, being simply meant to facilitate the evacuation of agricultural produce from the interior to the ports for exports in addition to serving as links between scattered human settlements thus permitting ease of administration.

The importance of transport infrastructure to a nation cannot be overemphasized as efficient transport infrastructure facilities act as catalysts for development. There is therefore cause for concern while considering the transport infrastructure base in Nigeria today which compares unfavorably with those of several African nations both in terms of quality and service coverage. In particular, the rural areas, where the bulk of the population resides, are largely deprived of basic pieces of transport infrastructure [12]. As a matter of fact, the sustainability of an urban area has to do with the ease of commuting within the various areas and this depends on the level of road network within the city. Development projects are intended to modify social and natural environments in order to create or enhance the economic wellbeing and livelihood and other benefits that are valued by society. This goal, however, can be denied through unanticipated or unintended negative social or environmental impacts that reduce desired benefits or, if severe enough, threaten the sustainability of the project. Socioeconomic benefits provided by road and highway projects include all-weather reliability, reduced transportation costs, and increased access to markets for local produce and products, access to new employment centers, employment of local workers on the project itself, better access to health care and other social services, and strengthening of local economies [11].

However, roads and highways can produce complex negative impacts. The impacts of improvement, rehabilitation and maintenance projects, although usually more limited, can still be significant, not only on natural resources and systems but also on the social and cultural environment. The transport sector is a significant source of employment. Employment benefits are likely to be both direct (operations and maintenance of infrastructure) and indirect (surplus services and materials), with associated changes in income and livelihoods for those employed. It is anticipated that the skill-base of the local labour pool will be strengthened, thereby enhancing prospects for future employment. Road construction and maintenance activities may also affect socio-economic conditions by creating more difficult trading conditions, thus having a negative effect on livelihoods. Activities such as noise or dusty/odorous equipment or materials stockpiles may discourage trading in immediate vicinity. Some traders may easily relocate nearby, however some may not. Although numbers may be small, effects could be significant by increasing individuals" vulnerability to poverty. Finally, local trading may increase at some locations due to the presence of local workforces [5].

A lot of research has been carried out on impact of road construction and expansion, Martinez and Viegas [8] tried to temper the high expectations with the qualification that transport holds no special inherent properties capable of initiating growth. Rather they argued it should be considered a necessary but not sufficient component of infrastructural investment, which is as unpredictable as other components in terms of its ability to generate development.

The rate at which settlements spring up must be of serious concern to any caring government. This is because it is government responsibility to provide infrastructure for the citizenry. Problems of accessibility is not limited to sprawl settlements, in areas that are well planned and where developments are legal, house owners erect expensive mansions all over without given adequate consideration to the issues of good roads. They look on governments to provide them with roads. Inability on their part to give the issue of good roads topmost priority is as a result of their ignorance on what effect roads improvements have on property values.

Inadequate provision of transport infrastructure and services provide a basis for explaining the incidence of poverty across various Nigerian communities in both urban and rural areas. It is clearly established that inadequate transport facilities and services as well as the constraints imposed on the mobility and accessibility of people to facilities such as markets, hospitals and water sources have grave implications on deepening poverty levels [15]. Thus, there is need for urgent policy measures to address the prevailing travel and transport problems. The importance of transport infrastructure to a nation cannot be overemphasized as efficient transport infrastructure facilities act as catalysts for development. There is therefore cause for concern while considering the transport infrastructure base in Nigeria today which competes unfavorably with those of several African nations both in terms of quality and service coverage. In particular, the rural areas, where the bulk of the population resides, are largely deprived of basic pieces of transport infrastructure [1]. Permanent occupancy of the open space of a publicly owned right-of-way quite commonly invites encroachment of local community activities onto the roadside, the footpaths, the bus stops, and even the road surface itself. These activities take many forms, including the selling of goods, whether from individual 
kiosks or more expansive markets; small businesses such as cafes and vehicle repair shops; uncontrolled stops by buses, taxis, and informal public transport; unregulated parking, often associated with business activities; the production of bricks on the road surface; and the growing of crops and the drying of farm produce within the road reserve. Added to this list of activities are social activities associated with the roadside which are far from illegal. In rural areas, in particular, but also in urban areas and at entrances to towns and villages, the roadside provides a social venue. People congregate along the roads to talk, smoke, and drink or watch the traffic [10].

As a matter of fact, the sustainability of an urban area has to do with the ease of commuting within the various areas and this depends on the level of road network within the city. Road development projects are intended to modify social and natural environments in order to create or enhance the economic well-being and livelihood and other benefits that are valued by society. This goal, however, can be denied through unanticipated or unintended negative social or environmental impacts that reduce desired benefits or, if severe enough, threaten the sustainability of the project. Socio-economic benefits provided by road and highway projects include all-weather reliability, reduced transportation costs, and increased access to markets for local produce and products, access to new employment centers, employment of local workers on the project itself, better access to health care and other social services, and strengthening of local economies [9].

Transport infrastructural development remains a major tool for achieving the aspirations of the newly introduced economic principles of the Federal Government of Nigeria, the National Economic Empowerment and Development Strategy (NEEDS). However, the condition of Nigerian roads has not ceased to amaze discerning observers and in effect, the roads have been ranked among the worst in the world. A significant portion of post independence studies on transport systems have been devoted to examination of successive Nigerian government's budgetary allocations and development in the transport sector in general [14]. Increasing level of traffic congestion is an inescapable result of strong economic activity and life in urban areas. Realistically, large metropolitan regions lack the resources, citizen support, and ultimately the space to provide for uncongested automobile travel. About half of congestion delay occurs in areas where demand has reached or exceeded capacity; the other half is due to incidents including weather, accidents, stalled vehicles and roadside distractions.
Sustainable development requires governments to provide public facilities and infrastructure that ensure safety and security, health and welfare, social and economic enhancement, and protection and restoration of the natural environment [17].

An early step in the process of providing such facilities and infrastructure is the acquisition of appropriate land. In some cases, several locations could be suitable for a facility and the government may be able to purchase land at one of the locations through the land market. In other cases, specific land parcels are required, for example, in order to accommodate the route of a new road, the protection of certain areas from flooding, or the fulfillment of requirements of redistributive land reform legislation. That land may not be on sale at the time it is required. In order to obtain land when and where it is needed, governments have the power of compulsory acquisition of land: they can compel owners to sell their land in order for it to be used for specific purposes [19]. These projects are both necessary and mandatory in a state and they can have both negative and positive impacts on the residents of that state especially the informal sector of the state which is what this paper sets out to consider. The growth of an urban area due to influx of people in search of employment usually takes its toll on the land and the built environment. This is evident by the growth of squatter settlements, illegal occupation of government land and erection of illegal structures on any open space in the city. As a greater percentage of urban workers are unable to get white collared jobs, the informal sector of the economy grows. The informal economy contributes as much as $40 \%$ of Gross Domestic Product and employs up to $60 \%$ of the labour force in developing countries. It is characterized by lack of organized wage structure, paid work on a casual basis, irregular jobs and self-employment without earning pensions and without paying taxes. This sort of employment is common in the urban areas of developing countries and women accounts for sixtynine percentage of the urban economy [16]. The urbanization of poverty no doubt led to the emergence of the informal sector.

The informal sector consists of those activities characterized by ease of entry into the activity concerned, reliance on indigenous resources, family ownership of enterprises, small scale of operations, labor intensive and adaptive technology, and skills acquired outside the formal school system and unregulated and competitive markets [18]. Gerrit [6] is of the view that the impact of an improved road network on property value depends on demographic segmentation of the neighborhood. 


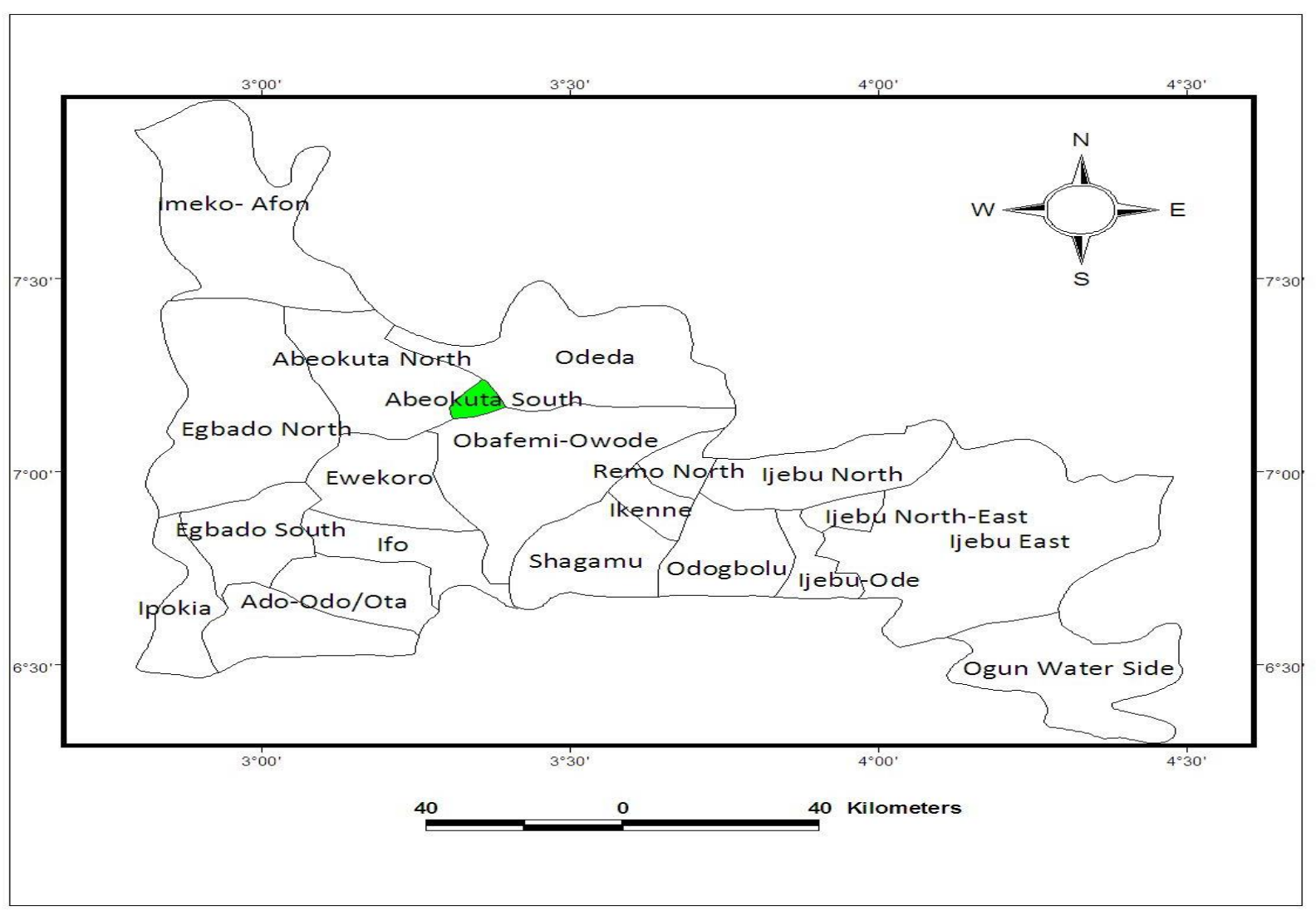

Fig.1. Map of Ogun state Showing Abeokuta South and Abeokuta North Local Government Source: - Ogun State Ministry of Land and Survey (2017)

It is against this background this study is set out to ascertain how Highway development and road expansion affect the structure and general setting of an urban area of Abeokuta city in Ogun State. See Figure 1.

\section{MATERIALS AND METHODS}

The source data for this research work consists of administration of questionnaires, oral and personal observation in the study area.

The questionnaires were used to gather information from resident chosen through simple random sampling from the study area. the questionnaire sought information on the socio-economic attributes, the present state of highway development, the level of road expansion, the effect of road expansion on traffic flow,

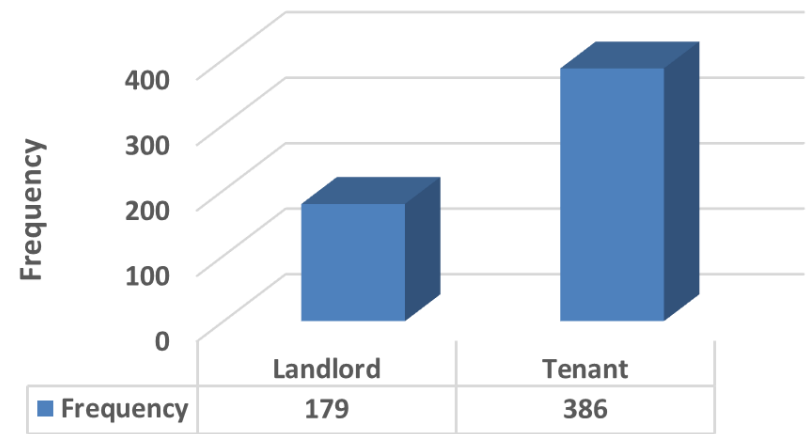

Fig. 2: Residence Status (Structure) of respondents the effect of road expansion of value of houses, the effect of road expansion on rents and leases and the solutions to the problems facing highway development and road expansion in the study area.

A total number of 565 respondents were selected using random sampling technique. The data collated were analyzed using simple descriptive and analytical statistics.

\section{RESULTS AND DISCUSSION}

3.1 Socio-Economic Characteristics of the respondents. Analysis of the survey carried out showed that status distribution of the respondents revealed that 179 of the respondents representing $31.7 \%$ are landlord and 386 of the respondents representing $68.3 \%$ are tenant.

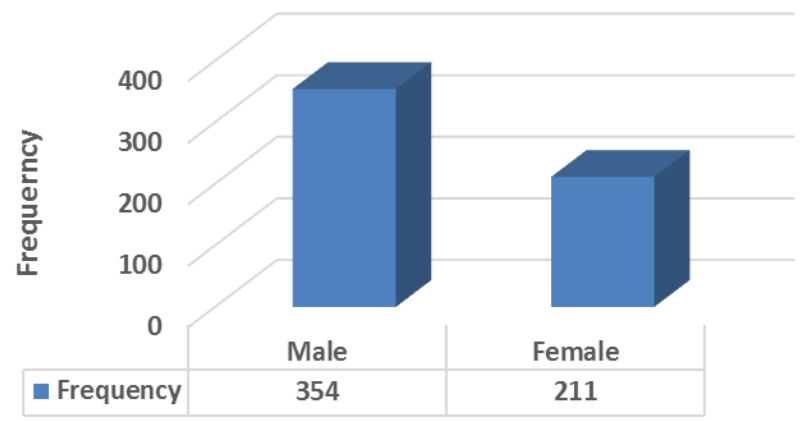

Fig 3: Gender Structure of respondents 


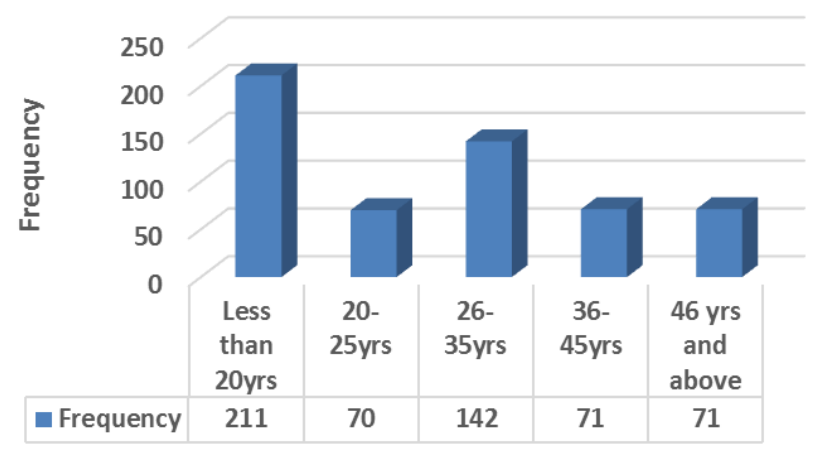

Fig. 4: Age of the respondents

Analysis of the survey carried out on the sex distribution of the respondents revealed that 354 of the respondents representing $62.7 \%$ are male and 211 of the respondents representing $37.3 \%$ are females.

The field survey revealed that 211 of the respondents representing $37.3 \%$ are below 20 years of age, 70 of the respondents representing $12.4 \%$ are between the ages of 20 to 25 years, 142 of the respondents representing $25.1 \%$ are between the ages of 26 and 35 years, 71 of the respondents representing $12.6 \%$ are between the ages of 36 to 45 years. 71 of the respondents representing (12.6\%) are between the ages 46 and above.

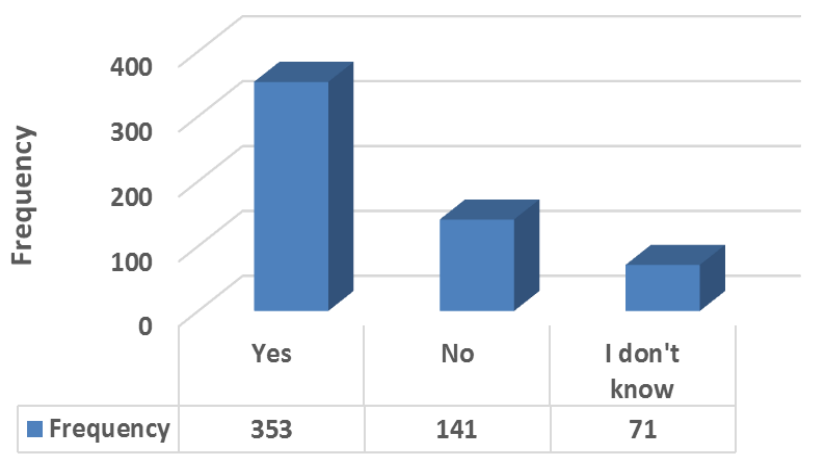

Fig. 6: Effect of Road Expansion on Rent, and leases.

Resident responses shown that 213, representing $37.7 \%$ of the respondents said the traffic flow in the study area is excellent, 141 representing $25 \%$ said it is very good, 70 representing $12.4 \%$ said good, 70 representing $12.4 \%$ said fair while 71 representing $12.6 \%$ said poor. From this we can conclude that the traffic flow in the study area is very good.

Analysis shows that 353 representing 62.5\% said Yes they believe that road expansion has effect on rents and leases in the study area, 141 (25\%) said no while $71(12.6 \%)$ said they don't know as shown above. See plate 1 and 2 below

\section{Hypothesis 1:}

Number of highway expansion has no significant effect on settlement in Abeokuta city.

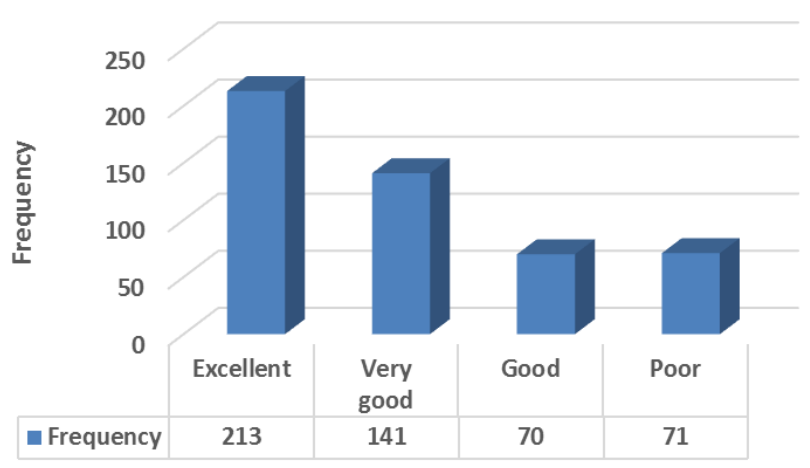

Fig. 5: Analysis of Traffic flow in the study Area

In table 1, number of highway expansion, accounts for $16 \%$ of the total variance in the settlement in Abeokuta with a level of significance of 0.00 at $5 \%$ level of significance. This percentage is significant, thus, number of highway expansion has a relationship with the settlement in Abeokuta; this means that when the highway is expanded and in good shape there will be significant increase in settlement.

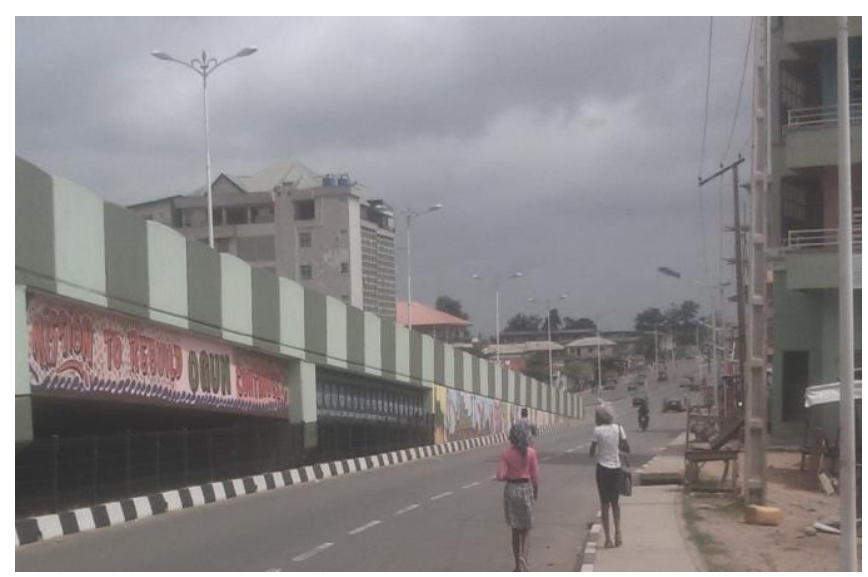

Plate 1: Highway infrastructure at Ibara in Abeokuta City. Source: Author Field Survey 2017

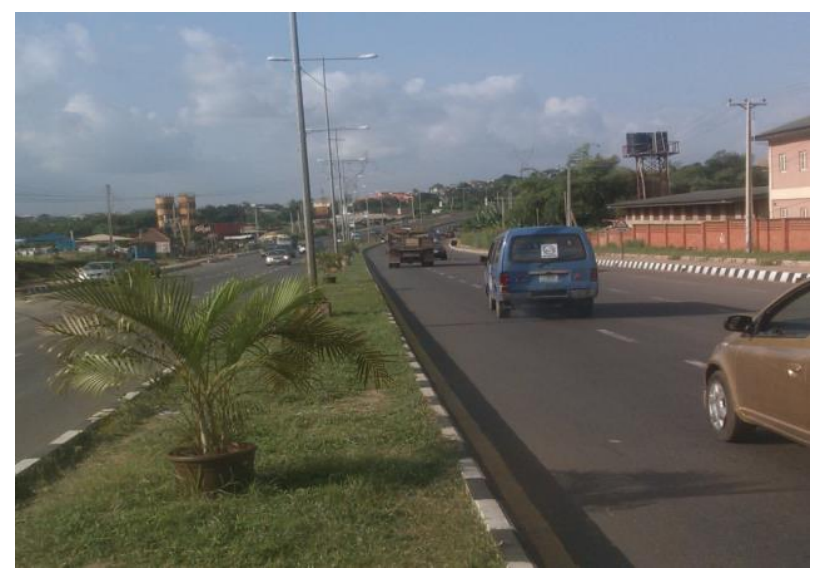

Plate 2: Improved Highway along Abiola way in Abeokuta City. Source: Author Field Survey, 2017. 
Table 1: ANOVA Result 1

\begin{tabular}{|l|l|l|l|l|l|l|}
\hline \multicolumn{7}{|c|}{$\mathrm{R}=0.407 ;$ R Square $=0.165 ;$ Adjusted R square $=0.164 ;$ Standard error $=0.648$} \\
\hline Model & Sum of squares & Df & Mean Square & F & Sig. & Remark \\
\hline 1 Regression & 46.806 & 1 & 46.806 & 111.451 & $0.000^{\mathrm{b}}$ & Significant \\
Residual & 236.443 & 563 & 0.420 & & & P $<0.00$ \\
Total & 283.250 & 564 & & & & \\
\hline
\end{tabular}

Table 2: ANOVA Result II

\begin{tabular}{|l|l|l|l|l|l|l|}
\hline \multicolumn{7}{|c|}{$\mathrm{R}=0.310 ;$ R Square $=0.096 ;$ Adjusted R square=0.095; Standard error $=0.664$} \\
\hline Model & Sum of squares & Df & Mean Square & F & Sig. & Remark \\
\hline 1 Regression & 26.453 & 1 & 26.453 & 60.053 & $0.000^{\text {b }}$ & Significant \\
Residual & 248.000 & 563 & 0.440 & & & P $<0.00$ \\
Total & 274.453 & 564 & & & & \\
\hline
\end{tabular}

Table 3: ANOVA Result III

\begin{tabular}{|l|l|l|l|l|l|l|}
\hline \multicolumn{7}{|c|}{$\mathrm{R}=0.906 ;$ R Square $=0.821 ;$ Adjusted R square $=0.820 ;$ Standard error $=0.300$} \\
\hline Model & Sum of squares & Df & Mean Square & F & Sig. & Remark \\
\hline 1 Regression & 232.439 & 1 & 232.439 & 2575.505 & $0.000^{b}$ & Significant \\
Residual & 50.811 & 563 & 0.090 & & & P $<0.00$ \\
Total & 283.250 & 564 & & & & \\
\hline
\end{tabular}

Source: Authors computation, 2017

\section{Hypothesis II:}

Traffic flow has no significant effect on development in Abeokuta city.

In table 2, traffic flow, accounts for $9 \%$ of the total variance in the development in Abeokuta city with a level of significance of 0.00 at $5 \%$ level of significance. This percentage is significant, thus, traffic flow has a relationship with development in Abeokuta city; this means that when traffic flows ceaselessly there will development in Abeokuta.

\section{Hypothesis III:}

Highway development and road expansion has no significant effect on value of houses.

In table 3 , highway development and road expansion, accounts for $82 \%$ of the total variance in the value of houses with a level of significance of 0.00 at $5 \%$ level of significance. This percentage is significant, thus, highway development and road expansion has a strong relationship with value of houses; this means that when there is highway development and road expansion there will be increase in the value of houses.

\section{CONCLUSION}

Good road projects clearly contribute to poverty reduction by improving the living conditions of people and by augmenting the opportunities available for trade and employment. The economic development of Nigeria has reflected the development of her transport systems. This is particularly true of the road transport system, which is by far the most widely used mode of transport in the country. Of all commodity movements to and from the sea-ports, at least two-thirds are now handled by road transport while up to $90 \%$ of all other internal movements of goods and persons take place by roads [13]. Transport can contribute to the economy directly through addition to capital stock via increases in transport infrastructure. Transport provides the arteries through which the economic life of the people, information and raw materials as well as finished products can be moved from one place to the other [3]. This therefore helps to build and maintain the society thereby leading to economic growth. It is essential to state that, the huge fund sunk into the construction, rehabilitation, and maintenance of roads in Nigeria in the last three decades is badly reciprocated by the poor and deplorable current state of these roads.

\section{REFERENCES}

[1] Adebayo, M.. The State of Urban Infrastructure and Its Effects on Property Values in Lagos, Nigeria, Journal of Land Use and Development Studies.2(1), 108-122, 2006.

[2] Aderamo, A.. A Graph Theoretic Analysis of IntraUrban Road Network in Ilorin, Nigeria, Journal of the Nigerian Institute of Social and Economic Research, Vol 17 Nos 1. pgs 221-240, 2003.

[3] Badejo, B. A. Transporting The Future Today: Portrait of Nigeria. 65 $5^{\text {th }}$ Inaugural Lecture. Olabisi Onabanjo University, Ago Iwoye, 2014.

[4] Cooper, M.C. Lambert, D. M. and Pagh, J. D. Supply chain management more than a new name for 
logistics, International Journal of Logistics Management, Vol. 8, No. 1, 1-13, 1998

[5] Cracknell, J. A.. Experience in urban traffic management and demand management in developing countries, World Bank Urban Transport Strategy Review, Background Paper, the World Bank, Washington, D.C. 2000.

[6] Gerrit, K. The Determinants of Residential Property Values: Implications for Metropolitan Planning. Journal of Planning Literature, Vol. 12 No. 3, 266-282 Journal of Property Management, Vol. 18, No. 5, 366-374, 1998.

[7] Mabogunje, A. L.: Urbanisation in Nigeria, $A$ constraint on Economic Development, University of London Press. 1980.

[8] Martínez, L.M., Viegas, J. M... Effects of transportation accessibility on residential property values. Transp. Res. Rec: J. Transp. Res. Board 2115 (1), 127-137. 2009.

[9] Mike Hrymark Mobility Transformation, Autonomous Ann Arbor put on behind the wheel, future mobility. Mobility Transformation Center, University if Michgan. Michgan University Press. 2015.

[10] Oladapo W. A., Transport Operations and Environmental Pollution. Unpublished M.SC Thesis, Center for Transport Studies Olabisi Onabanjo University, Ago Iwoye. 2001.

[11] Olokesusi, 0. Environmental Sustainability in Nigeria in 2010, Edited by Philip, A.O and Titilola,
S. T: Nigeria Institute of social and Economic Research (NISER), Ibadan. Pp. 245-262. 1997.

[12] Olomola, A. S. Understanding poverty in Nigeria: highlights from NISER review of Nigerian development in NISEREEL, the Magazine of the Nigerian Institute of Social and Economic Research, 4 \& 5, Ibadan. 2003.

[13] Onakomaya, S. O. et al. Ogun state in Map. pp. 13, 135, 174-176. 1992.

[14] Oni, A. O.. A Study of the Accessibility and Connectivity of Ikeja Arterial Roads Journal of Land Use and Development Studies. 3(1), 108122, 2007.

[15] Oyesiku 0. O. From Womb to Tomb, Inaugural lecture, Olabisi Onabanjo University, Ago Iwoye, Ogun State, 2002.

[16] Stephanedes, Yorgos J., and David Eagle. "Highway Impacts on Regional Employment." Journal of Advanced Transportation Vol. 21: 67-79. 1995.

[17] Tillema, T., Hamersma, M., Sussman, J. M., Arts, J. Extending the scope of highway planning. accessibility, negative externalities and the residential context. Transp. Rev. 32 (6), 745-759, 2012.

[18] Transportation Research Board. Expanding Metropolitan Highways, Washington, DC: National Academy Press. 1995.

[19] Tse, R. Y. and Love, P. E. Measuring Residential Property Values in Hong Kong. 2000. 